Article

\title{
Evaluation of Terpenes Psiadin, Plectranthone, and Saudinolide as Selective Anti-Cancer Agents against Hepatic Carcinoma Cells
}

\author{
Khaled Y. Orabi 1,*, Mohamed S. Abaza ${ }^{2}$, Rajaa Al-Attiyah ${ }^{3}$ and Yunus A. Luqmani ${ }^{4}$ \\ 1 Department of Pharmaceutical Chemistry, Faculty of Pharmacy, Kuwait University, Safat 13110, Kuwait; \\ ky.orabi@ku.edu.kw \\ 2 Department of Biological Sciences, Faculty of Science, Kuwait University, Safat 13060, Kuwait; \\ abazams@yahoo.com \\ 3 Department of Microbiology and Immunology, Faculty of Medicine, Kuwait University, Safat 13110, \\ Kuwait; rj.alattiyah@hsc.edu.kw \\ 4 Department of Pharmaceutical Chemistry, Faculty of Pharmacy, Kuwait University, Safat 13110, Kuwait; \\ yunus.luqmani@ku.edu.kw \\ * Correspondence: ky.orabi@ku.edu.kw ; Tel.: +965-2 463-6158
}

\begin{abstract}
Plant-derived terpenes have aroused considerable interest as chemotherapeutic agents for a variety of diseases. This study aimed at the isolation and purification of the scarce terpenes psiadin, plectranthone and saudinolide from their respective plants, followed by the determination of antiproliferative activity, against hepatic cancer cell lines (HepG2, Hep3B), and the potential molecular mechanisms. Time- and dose-dependent cytotoxicity, evaluated using MTT and colonyforming assays, were exhibited by psiadin and plectranthone against the cancer cells. Flow cytometry showed that these two terpenes blocked cell cycle progression and induced mitochondrial-mediated apoptosis, particularly through increased cytochrome $\mathrm{c}$ and disruption of mitochondrial membrane potential. Additionally, they initiated the generation of reactive oxygen species as well as inhibiting NF-KB. Psiadin lowered several essential cyclins and cyclin-dependent kinases and reduced RB activation. It was concluded that psiadin, in particular, has a significant therapeutic potential with the biggest advantage of differentiating between cancer and normal cells which is acutely lacking in current cytotoxic drugs. Its precise mode of action needs further investigation but appears predominantly to cause cell cycle arrest by interfering with cyclin production. It will be important to determine, in future studies, whether these terpenes will similarly inhibit other cancer cell lines and retain its activity against tumors in vivo.
\end{abstract}

Keywords: Terpenes; Hepatic carcinoma; Apoptosis.

\section{Introduction}

The global cancer burden is escalating significantly, with projections of 28 million new cases and 16 million cancer deaths by 2040 [1]. Post-surgical cancer chemotherapy relies heavily on a variety of general cytotoxic agents. However, most are associated with collateral damage to normal tissues that are frequently severe and intolerable, limiting their usefulness. Thus, there is a great need for new drugs that are more cancer-selective with lesser undesirable side effects [2]. Natural products hold historical significance in various folkloric medicines and form the basis of many modern-day drugs. Phytochemicals are the only sources for several medications that are almost impossible to get from other sources. Also, they serve as prototypes by providing pharmacophores for many synthetic drugs [3]. Indeed, a significant proportion of current chemotherapeutics is either natural or derived from them [4]. Moreover, conjugation of toxic natural products to monoclonal antibodies or polymeric 
carriers can lead to more efficacious targeted therapies [5-9]. Between 1981 and 2019, 247 such chemical entities were approved as anticancer drugs [2].

Of these phytochemicals, terpenes, including cembranoids, are the largest group with a wide range of biological activities, two prominent examples with the anticancer application being paclitaxel and limonene. A large number of terpenes have been identified in extracts of plants from the genera of families such as Euphorbiaceae, Lamiaceae, and Asteraceae, that are endogenous to the Arabian Peninsula and extensively used in local folkloric medicine [10-13]. This study we focused our attention on three terpenes; psiadin, plectranthone, and saudinolide (Figure 1a).

Psiadin is a diterpene isolated from the aerial parts of Psiadia arabica Jaub. et Spach. (Asteraceae) ) [14]. Over seventy compounds, including flavonoids, phenylpropanoids, coumarins, and terpenoids, have been isolated from the genus Psiadia, of which only the flavonoids are reported to have bioactivity [15]. Crude extracts and essential oils of Psiadia species have demonstrated antimicrobial [16, 17], anti-viral [18, 19], antiplasmodial [20, 21], and anti-inflammatory activities. [21, 22].

Phytochemical studies on Plectranthus species indicate the presence of eudesmane sesquiterpenes, labdane, abietane, ent-kaurane diterpenoids and triterpenoids [23]. The plant itself has a folkloric record of use in southern and western regions of Arabia as a disinfectant and deodorant, and for digestive and respiratory diseases. Thymol, the main constituent responsible for the culinary uses of the fresh plant, is responsible for its antibacterial property [13]. The sesquiterpene plectranthone has been identified in Plectranthus cylindraceus Hochst. ex Benth (Lamiaceae) [23].

The 6,7-secolabdane diterpene saudinolide was identified as a constituent of Clutyia richardiana L. (Euphorbiaceae). This plant is characterized by its unpleasant odor and intense bitter taste [10]. Some of the isolated diterpenes, saudin for example, have a significant hypoglycemic effect in nonalloxanized fasted mice [11, 12].

Using standard chromatographic and spectral analyses protocols, we isolated, purified and identified these three terpenes from their respective plant sources and determined their effects on human hepatic cancer cell lines. The data suggest that plectranthone and, more especially psiadin have selective cytotoxic activity towards the cancer cells. They also induced greater cell death rates at equivalent concentrations than several drugs currently utilized in cancer chemotherapy through various discussed mechanisms.

\section{Results}

\subsection{Extraction, isolation and, identification of terpenes}

Psiadia arabica chloroform extract was solvent-portioned and chromatographed to yield $1380 \mathrm{mg}$ of impure psiadin (Figure 1a). Crystallization from methylene chloride/ethyl acetate gave $813 \mathrm{mg}$ ( $0.041 \%$ yield) of pure psiadin as colorless needles.

Psiadin: colorless needles; mp 164-165 ${ }^{\circ} \mathrm{C} ;[\alpha]_{\mathrm{D}}-120^{\circ}\left(c\right.$ 0.1, $\left.\mathrm{CHCl}_{3}\right) ; \mathrm{UV}(\mathrm{MeOH}) \lambda_{\max }(\log \varepsilon) 282(2.14)$ $\mathrm{nm}$; IR (KBr) $v_{\max } 3422,1690 \mathrm{~cm}^{-1} ;{ }^{1} \mathrm{H}$ NMR $\left(\mathrm{CDCl}_{3}, 600 \mathrm{MHz}\right)$ see Table $1 ;{ }^{13} \mathrm{C}$ NMR ( $\left.\mathrm{CDCl}_{3}, 150 \mathrm{MHz}\right)$ see Table 1; HRESMS m/z; $301.3257\left[\mathrm{M}-\mathrm{H}_{2} \mathrm{O}+\mathrm{H}\right]^{+}, 283.3109\left[\mathrm{M}-2 \mathrm{H}_{2} \mathrm{O}+\mathrm{H}\right]^{+}$.

Similarly, the $95 \%$ ethanol extract of Plectranthus cylindraceus was purified to afford, after crystallization from ethyl acetate/petroleum ether, $1400 \mathrm{mg}$ of plectranthone $(0.13 \%$ yield $)$ as pure colorless prisms.

Plectranthone: colorless prisms; $\mathrm{mp} 134-135^{\circ} \mathrm{C}$; $[\alpha]_{\mathrm{D}}-36.9^{\circ}\left(c\right.$ 0.03, $\left.\mathrm{CHCl}_{3}\right) ; \mathrm{UV}(\mathrm{MeOH}) \lambda_{\max }(\log \varepsilon)$ 237 (3.13) nm; IR (KBr) $v_{\max }$ 2900, 1725, $1670 \mathrm{~cm}^{-1}$; ${ }^{1} \mathrm{H}$ NMR $\left(\mathrm{CDCl}_{3}, 600 \mathrm{MHz}\right)$ see Table 1; ${ }^{13} \mathrm{C}$ NMR 
$\left(\mathrm{CDCl}_{3}, 150 \mathrm{MHz}\right)$ see Table 1; HRESMS m/z; $277.2827\left[\mathrm{M}-\mathrm{CH}_{3} \mathrm{COOH}+\mathrm{H}\right]^{+}, \quad 217.2472[\mathrm{M}-$ $\left.2 \mathrm{CH}_{3} \mathrm{COOH}+\mathrm{H}\right]^{+}$.

The ethyl acetate extract of Cluytia richardiana aerial parts gave, after chromatography and crystallization, $450 \mathrm{mg}$ ( $0.028 \%$ yield) colorless granules identified as the diterpene saudinolide.

Saudinolide: colorless granules; $\mathrm{mp} 231-235^{\circ} \mathrm{C} ;[\alpha]_{\mathrm{D}}+98^{\circ}\left(c \quad 0.142, \mathrm{CHCl}_{3}\right) ; \mathrm{UV}(\mathrm{MeOH}) \lambda_{\max }(\log \varepsilon)$ 220 (4.30), 265 (3.90) nm; IR (KBr) $v_{\max } 3520(\mathrm{OH}), 1780$ ( $\gamma$-lactone), 1720 ( $\delta$-lactone), 1510, 1450, 1380 (br), 1200, 1190, 1050, 970, 860, 830, $735 \mathrm{~cm}^{-1} ;{ }^{1} \mathrm{H}$ NMR $\left(\mathrm{CDCl}_{3}, 600 \mathrm{MHz}\right)$ see Table 1 ; ${ }^{13} \mathrm{C}$ NMR $\left(\mathrm{CDCl}_{3}\right.$, $150 \mathrm{MHz})$ see Table 1; HRESMS $m / z[\mathrm{MH}]^{+} 389.2544\left[\mathrm{C}_{20} \mathrm{H}_{20} \mathrm{O} 8+\mathrm{H}\right]^{+}$.

Table 1. ${ }^{1} \mathrm{H}$ and ${ }^{13} \mathrm{C}$ NMR Data $\left(\mathrm{CDCl}_{3}\right)$ for Psiadin, Plectranthone and Saudinolide

\begin{tabular}{|c|c|c|c|c|c|c|}
\hline \multirow[b]{2}{*}{$\#$} & \multicolumn{2}{|c|}{ Psiadin } & \multicolumn{2}{|c|}{ Plectranthone } & \multicolumn{2}{|c|}{ Saudinolide } \\
\hline & $\begin{array}{c}\delta_{\mathrm{c}}, \\
\text { multiplicity }\end{array}$ & $\begin{array}{c}\delta \mathrm{H}, \\
\text { multiplicity } \\
(J \text { in } \mathrm{Hz})\end{array}$ & $\begin{array}{c}\delta c, \\
\text { multiplicity }\end{array}$ & $\begin{array}{c}\delta \mathrm{H}_{,} \\
\text {multiplicity } \\
(J \text { in } \mathrm{Hz})\end{array}$ & $\begin{array}{c}\delta_{c}, \\
\text { multiplicity }\end{array}$ & $\begin{array}{c}\delta \mathrm{H}, \\
\text { multiplicity } \\
(\mathrm{J} \text { in } \mathrm{Hz})\end{array}$ \\
\hline 1 & $48.6, \mathrm{CH}_{2}$ & $\begin{array}{l}\text { 1eq: } 2.61, \mathrm{~d} \\
(14.0) \\
\text { 1ax: } 2.72, \mathrm{~d} \\
(14.0)\end{array}$ & $47.8, \mathrm{CH}_{2}$ & $\begin{array}{l}2.06, d(15.8) \\
2.55, d(15.8)\end{array}$ & 73.0, CH & $5.93, \mathrm{~m}$ \\
\hline 2 & 212.7, C & --- & 198.4, C & --- & --- & --- \\
\hline 3 & $55.9, \mathrm{CH}_{2}$ & $\begin{array}{l}\text { 3eq: } 2.38, \mathrm{dd} \\
(14.0,1.5) \\
3 \text { ax: } 2.06, \mathrm{dd} \\
(14.0,1.5)\end{array}$ & $128.7, \mathrm{CH}$ & 5.90, br s & 172.7, C & --- \\
\hline 4 & 43.7, C & --- & 158.0, C & --- & 47.7, $\mathrm{CH}$ & $\begin{array}{l}2.9, \mathrm{dq}(1.3, \\
8.0)\end{array}$ \\
\hline 5 & $50.5, \mathrm{CH}$ & $1.22, \mathrm{~m}$ & $44.0, \mathrm{CH}$ & 3.01 , br s & $72.5, \mathrm{C}$ & --- \\
\hline 6 & $20.9, \mathrm{CH}_{2}$ & $\begin{array}{l}\text { 6eq: } 1.65, \mathrm{~m} \\
\text { 6ax: } 1.42, \mathrm{~m}\end{array}$ & 71.6, $\mathrm{CH}$ & 5.56, br s & $42.3, \mathrm{CH}_{2}$ & $\begin{array}{l}2.61, \mathrm{~d}(15.0) \\
2.54, \mathrm{~d}(15.0)\end{array}$ \\
\hline 7 & 40.4, $\mathrm{CH}_{2}$ & $1.56, \mathrm{~m}$ & $43.2, \mathrm{CH}$ & $0.90, \mathrm{~m}$ & 108.4, C & --- \\
\hline 8 & 44.0, C & --- & $20.9, \mathrm{CH}_{2}$ & $\begin{array}{l}1.38, \mathrm{~m} \\
1.60, \mathrm{~m}\end{array}$ & --- & --- \\
\hline 9 & $55.0, \mathrm{CH}$ & $1.10, \mathrm{~m}$ & $28.8, \mathrm{CH}_{2}$ & $\begin{array}{l}1.48, \mathrm{~m} \\
1.48, \mathrm{~m}\end{array}$ & $89.7, \mathrm{C}$ & --- \\
\hline 10 & $46.6, \mathrm{C}$ & --- & $38.6, \mathrm{C}$ & --- & 100.6, CH & $5.93, \mathrm{~s}$ \\
\hline 11 & $18.5, \mathrm{CH}_{2}$ & $1.54, \mathrm{~m}$ & 29.1, CH & $1.48, \mathrm{~m}$ & --- & $-{ }_{---}$ \\
\hline 12 & 32.7, $\mathrm{CH}_{2}$ & $1.46, \mathrm{~m}$ & $21.1, \mathrm{CH}_{3}{ }^{a}$ & $0.88, \mathrm{~d}(6.7)^{a}$ & $174.7, \mathrm{C}$ & --- \\
\hline 13 & 43.6, $\mathrm{CH}$ & $2.60, \mathrm{br} \mathrm{s}$ & $21.2, \mathrm{CH}_{3}{ }^{a}$ & $0.86, \mathrm{~d}(6.7)^{a}$ & $44.3, \mathrm{C}$ & --- \\
\hline
\end{tabular}




\begin{tabular}{|c|c|c|c|c|c|c|}
\hline 14 & $39.1, \mathrm{CH}_{2}$ & $\begin{array}{l}\text { 14eq: } 1.84, \\
\text { dd }(11,1.5) \\
\text { 14ax: } 1.10, \mathrm{~m}\end{array}$ & 69.7, $\mathrm{CH}_{2}$ & $\begin{array}{l}3.86, \mathrm{~d}(11.0) \\
4.40, \mathrm{~d}(11.0)\end{array}$ & 126.2, CH & $5.91, \mathrm{~d}(3.9)$ \\
\hline 15 & $44.7, \mathrm{CH}_{2}$ & $2.01, \mathrm{~m}$ & 23.2, $\mathrm{CH}_{3}$ & $1.99, \mathrm{~s}$ & $132.3, \mathrm{CH}$ & $\begin{array}{l}6.22 \text { dd (3.9, } \\
8.0)\end{array}$ \\
\hline 16 & 154.7, C & --- & $21.5, \mathrm{CH}_{3}$ & $2.03, s^{b}$ & $48.8, \mathrm{C}$ & --- \\
\hline 17 & 103.6, $\mathrm{CH}_{2}$ & $\begin{array}{l}4.82, \mathrm{~s} \\
4.76, \mathrm{~s}\end{array}$ & $21.5, \mathrm{CH}_{3}$ & $2.04, s^{b}$ & --- & --- \\
\hline 18 & $70.9, \mathrm{CH}_{2}$ & $3.85, \mathrm{~s}$ & $170.8, C^{b}$ & --- & --- & --- \\
\hline 19 & $65.4, \mathrm{CH}_{2}$ & $\begin{array}{l}3.74, \mathrm{~d}(10.5) \\
3.54, \mathrm{~d}(11.0)\end{array}$ & $171.2, C^{b}$ & --- & --- & --- \\
\hline 20 & $19.3, \mathrm{CH}_{3}$ & $1.06, \mathrm{~s}$ & --- & --- & --- & --- \\
\hline $2^{\prime}$ & --- & --- & --- & --- & $141.9, \mathrm{CH}$ & $7.68 \mathrm{~d}(1.0)$ \\
\hline $3^{\prime}$ & -- & --- & --- & -- & 124.3, C & --- \\
\hline $4^{\prime}$ & --- & --- & --- & --- & 108.7, CH & $\begin{array}{l}6.52, \mathrm{dd} \\
(1.0,1.8)\end{array}$ \\
\hline $5^{\prime}$ & -- & --- & --- & --- & $144.4, \mathrm{CH}$ & $7.48, \mathrm{t}(1.8)$ \\
\hline $\mathrm{OH}$ & -- & $5.5, \mathrm{br} \mathrm{s}$ & --- & -- & --- & $4.10, \mathrm{~d}(1.3)$ \\
\hline $\mathrm{OH}$ & -- & 5.6, br s & --- & -- & --- & --- \\
\hline $\mathrm{C}_{4}-\mathrm{CH}_{3}$ & -- & ---- & --- & --- & $15.5, \mathrm{CH}_{3}$ & $1.41, \mathrm{~d}(8.0)$ \\
\hline $\begin{array}{l}\mathrm{C} 13- \\
\mathrm{CH}_{3}\end{array}$ & --- & --- & --- & --- & $19.6, \mathrm{CH}_{3}$ & $1.19, \mathrm{~s}$ \\
\hline $\begin{array}{l}\mathrm{C} 16- \\
\mathrm{CH}_{3}\end{array}$ & --- & --- & --- & ---- & $16.5, \mathrm{CH}_{3}$ & $1.46, \mathrm{~s}$ \\
\hline
\end{tabular}

${ }^{a, b}$ Assignments may be interchanged within the same column

\subsection{Effect of the isolated terpenes on the growth of hepatocellular cancer cells}

Cytotoxicity of the tested terpenes towards normal human cells were tested using varying concentrations for 24-144 h. Psiadin exhibited minimal effect until the concentration exceeded 100 $\mu \mathrm{g} / \mathrm{mL}$ when there was about $10 \%$ cytotoxicity after $24 \mathrm{~h}$, increasing to $30 \%$ only with more prolonged exposure. Plectranthone and saudinolide toxicity did not exceed $30 \%$ at the highest concentration and longest culture time (data not shown). Treatment of the cancer cell lines with the three terpenes showed differential effects as assessed by MTT and colony-forming assays (Figure $1 b-d$ ). Psiadin exhibited significant time- and dose-dependent cytotoxicity on both cell lines with very similar efficacy. After $24 \mathrm{~h}$ exposure, about $50 \%$ of cells died at $100 \mu \mathrm{g} / \mathrm{mL}$ and, after $72 \mathrm{~h}$ exposure, there was over $50 \%$ cell death with $10 \mu \mathrm{g} / \mathrm{mL}$, with total cell kill observed with $60-80 \mu \mathrm{g} / \mathrm{mL}$. The cells' ability, pre-exposed to psiadin for $24 \mathrm{~h}$, to form colonies was reduced in a dose-dependent manner starting at $20 \mu \mathrm{g} / \mathrm{mL}$ for both cell lines. Plectranthone was also cytotoxic but required higher concentrations; for Hep3B, cells it achieved $50 \%$ cell kill at $125 \mu \mathrm{g} / \mathrm{mL}$ compared with $325 \mu \mathrm{g} / \mathrm{mL}$ for HepG2 cells after $72 \mathrm{~h}$ exposure. Similarly, it inhibited colony-forming ability to a much greater extent 
in Hep3B cells. Saudinolide, in contrast, had a minimal impact on HepG2 cells and 20-30\% cytotoxicity on Hep3B at the highest concentration tested after $72 \mathrm{~h}$ exposure. For this reason, it was not tested in the colony-forming assay and further experiments excluded saudinolide in view of its lack of appreciable effect.

In a separate series of experiments, we compared the efficacy of psiadin and plectranthone with four drugs that are currently used in the clinical management of various cancers. These results are illustrated in Figure 1c. As already observed in earlier experiments, on HepG2 cells, psiadin, after 24 $\mathrm{h}$, achieved $75 \%$ cell kill at $120 \mu \mathrm{g} / \mathrm{mL}$, extending to $100 \%$ after $72 \mathrm{~h}$ with $75 \mu \mathrm{g} / \mathrm{mL}$. Similar concentrations of ellipticine (ELP) and camptothecin (CPT) achieved 15-25\% cell kill after $24 \mathrm{~h}$ and $40-70 \%$ after $72 \mathrm{~h}$, while 5-fluorouracil (5FU) and doxorubicin (DOX) showed no effect at $24 \mathrm{~h}$ and only about $10 \%$ toxicity after $72 \mathrm{~h}$. Hep3B cells gave similar results. Plectanthrone after $72 \mathrm{~h}$ achieved a cell kill of approximately 50\% in HepG2 cells. This was more than with ELP and 5FU but less than with DOX and CPT. In Hep3B cells, plectranthone was the most effective of the five drugs. 
(a)

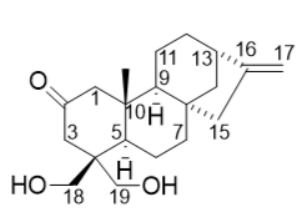

Psiadin

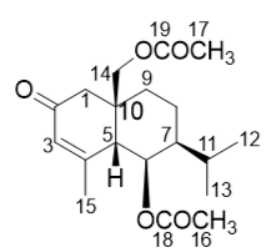

Plectranthone

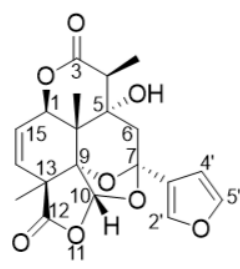

Saudinolide

(b)
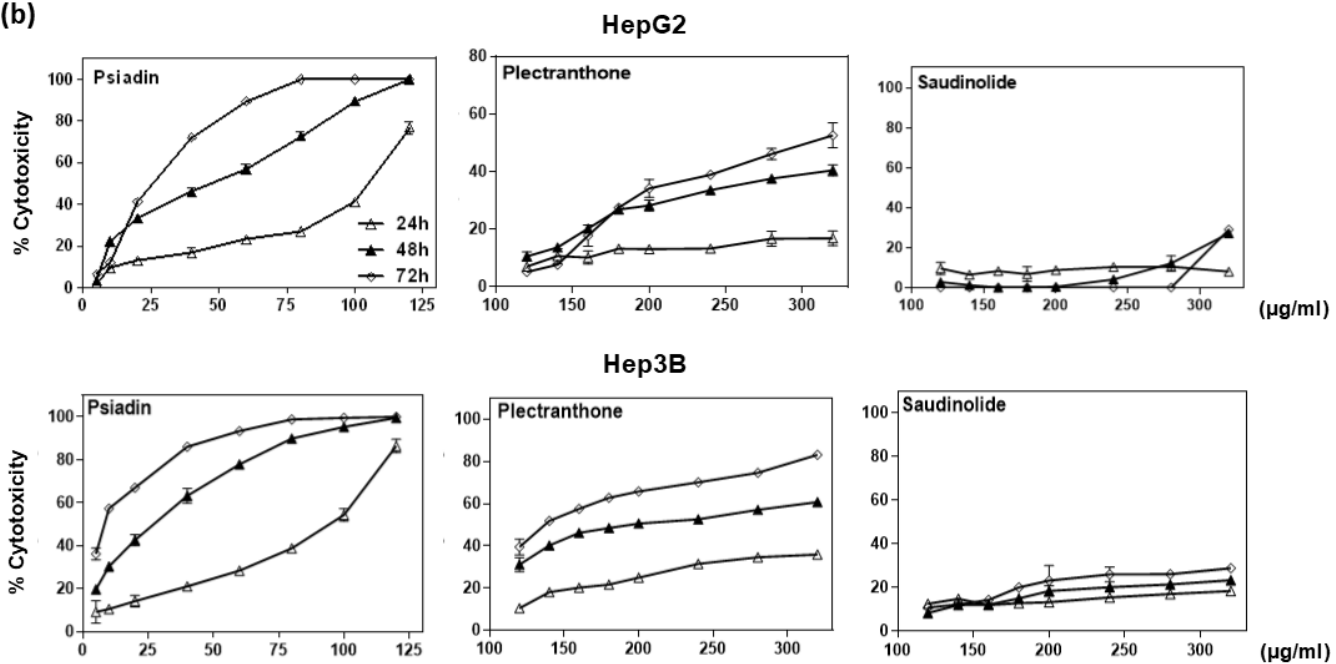

(c)
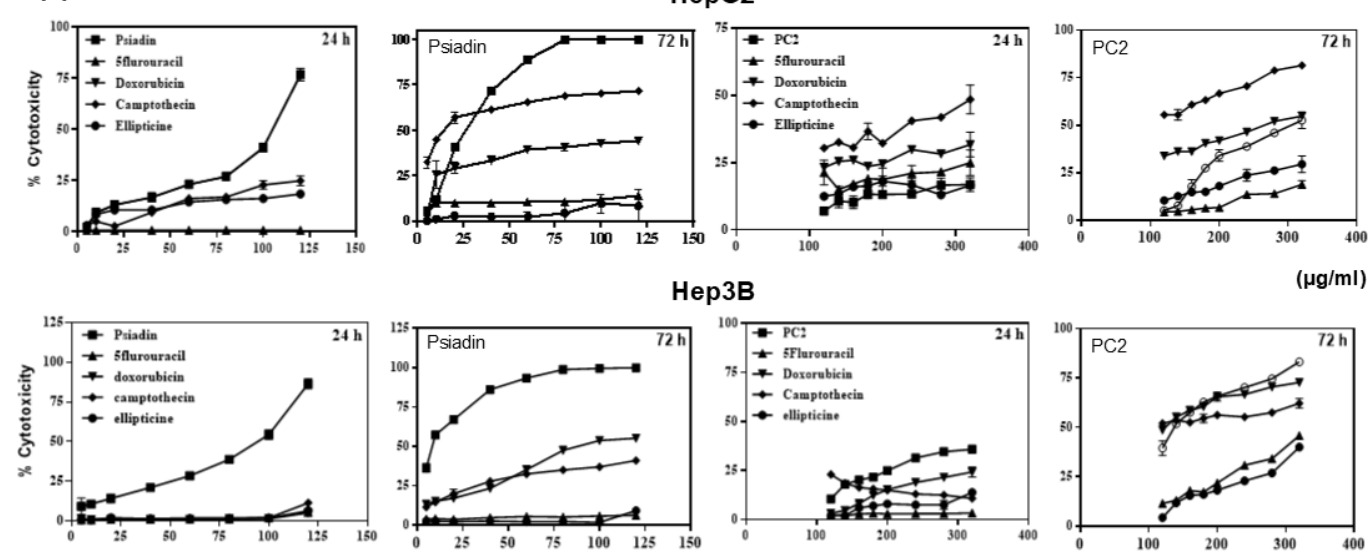

(d)

HepG2
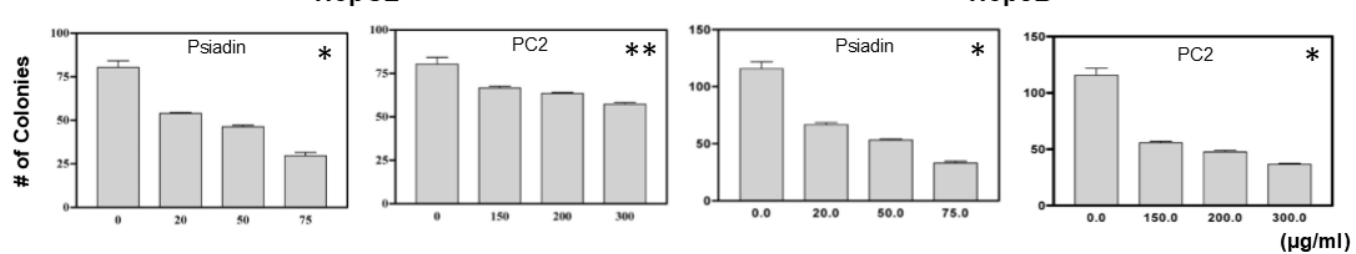

Figure 1. (a) Chemical structures of the isolated terpenes. (b) HepG2 and Hep3B cells were treated with different terpenes in a time- and dose-dependent manner, and cell viability was determined by MTT assay and expressed as \% cytotoxicity. (c) HepG2 and Hep3B cells were treated with different concentrations of psiadin, plectranthone (PC2) or standard chemotherapeutic drugs (5-fluorouracil, doxorubicin, camptothecin and ellipticine) for $24 \mathrm{~h}$ and $72 \mathrm{~h}$. Then, cell viability was measured by MTT assay and expressed as \% cytotoxicity. (d) Colony formation assay was performed to determine HepG2 and Hep3B cells viability, following treatment with psiadin and plectranthone (PC2) and incubation for 10-14 days. Each data point represents mean \pm SEM for triplicate samples expressed as percentage of treated to untreated condition. Asterisks denote significant difference from the control/vehicle, with $\mathrm{p}<0.01\left(^{*}\right)$ and $\mathrm{p}=0.05\left(^{* *}\right)$. 


\subsection{Effect of psiadin and plectranthone on cell cycle distribution of HepG2 and Hep3B cells}

The percentage of cells in each stage of the cell cycle was determined by flow cytometry following 24 $\mathrm{h}$ exposure to increasing concentrations of the two terpenes. These data (from one representative experiment, repeated three times) are shown in Figure 2a. Treatment of HepG2 cells with psiadin resulted in increased accumulation of cells in G1/G0 and in G2/M phases with consequently fewer cells were entering the $S$ phase as compared with vehicle (DMSO) treated cells. With plectranthone, we did not observe any significant change in cell cycle distribution. In the case of HepB3 cells treated with psiadin, the percentage of cells in G1/G0 did not change, whereas they increased by about $40 \%$, with less cells in S-phase with increasing drug concentration. With plectranthone, on the other hand, there was a small increase in the percentage of cells in G1/G0 with less in S phase and G2/M.

\subsection{Effect of psiadin and plectranthone on apoptosis in Hep $\mathrm{G} 2$ and Hep $3 B$ cells}

Figure $2 \mathrm{~b}$ illustrates the data from one representative experiment (repeated three times with overall similar outcome) on the effect of treating cells with 100 and $400 \mu \mathrm{g} / \mathrm{mL}$ of psiadin. For psiadin treated HepG2, there was a large decrease in the proportion of viable cells from about 91 to $37 \%$ and very substantial increases in early apoptotic, late apoptotic, and necrotic cells. After plectranthone treatment, there was a smaller fall in viable cells of about from 90 to $75 \%$, with corresponding rise in late apoptotic and necrotic cells. For Hep3B cells, psiadin reduced living cells from 81 to just $2 \%$, increased early apoptotic cells from 2 to $5 \%$, late apoptotic cells from 12 to $82 \%$, and necrosis from $5.4 \%$ to $11 \%$. Plectranthone induced apoptosis in both HepG2 and Hep3B only at high concentrations ( $\geq 600 \mu \mathrm{g} / \mathrm{mL}$; data not shown). 
(a)
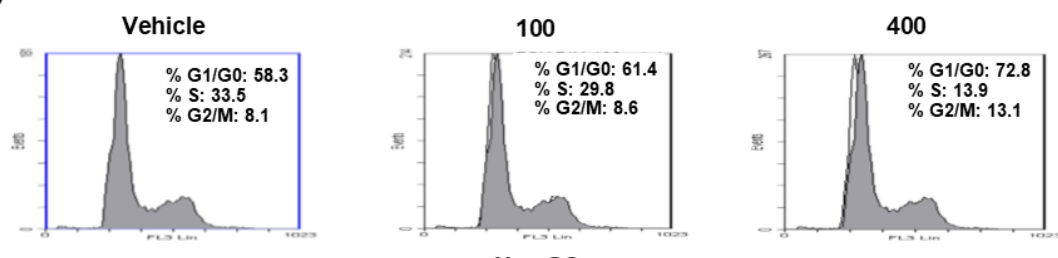

Psiadin $(\mu \mathrm{g} / \mathrm{ml})$
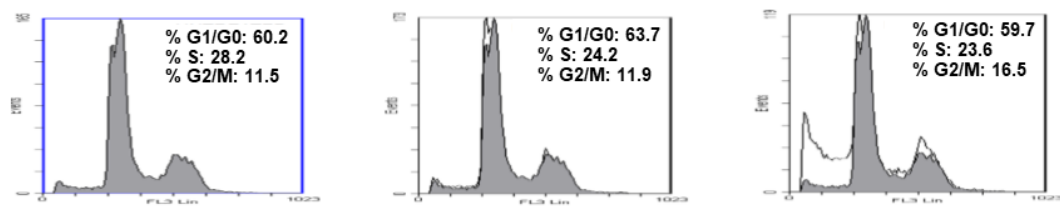

Hep3B
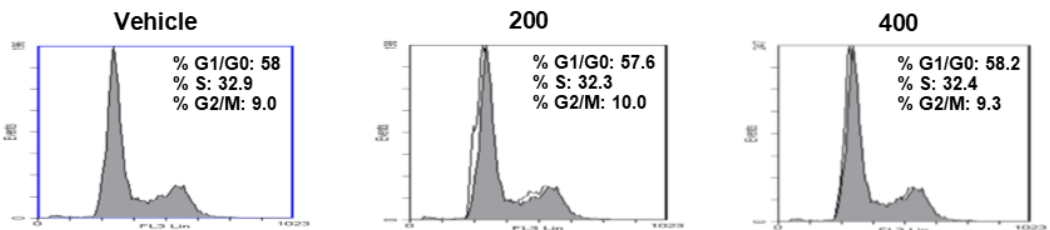

Plectranthone $(\mu \mathrm{g} / \mathrm{ml})$

HepG2
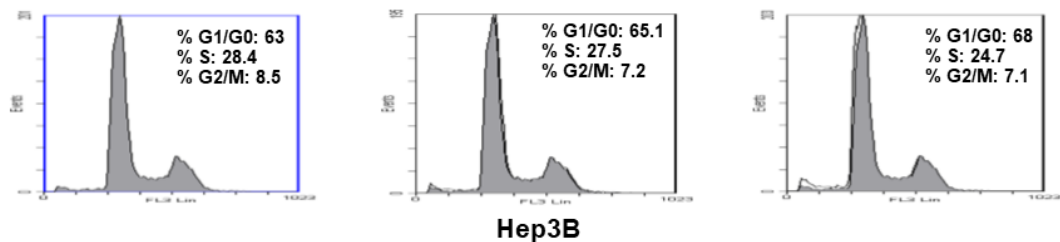

(b)
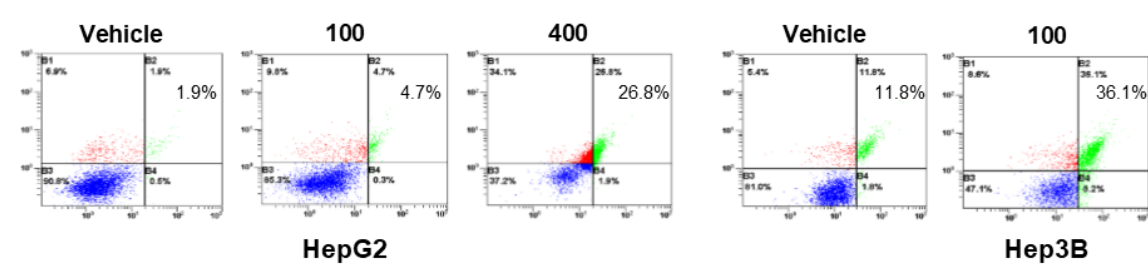

Psiadin ( $\mu \mathrm{g} / \mathrm{ml})$

400

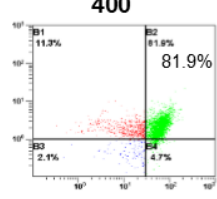

Annexin V-FITC

Figure 2. Psiadin and plectranthone modulate cell cycle and induce apoptosis in hepatic cancer cells. (a) Alterations in the cell cycle distribution were seen in HepG2 and Hep3B cells treated with the indicated concentrations of psiadin and plectranthone for $24 \mathrm{~h}$. At least three samples were analyzed, and 20,000 events were scored for each sample. The vertical axis represents the relative number of events and the horizontal axis represents the fluorescence intensity. (b) HepG2 and Hep3B cells were treated with the indicated concentrations of psiadin for $24 \mathrm{~h}$, followed by staining with Annexin $\mathrm{V}$ FITC/PI, and then analyzed by flow cytometry. B1: \% necrosis, B2: \% late apoptosis, B3: \% living cells, B4: \% early apoptosis.

\subsection{Changes in mitochondrial membrane potential induced by psiadin and plectranthone}

A fluorescent dye from Abcam was used for measuring the change $(\Delta \psi \mathrm{m})$, in the mitochondrial membrane potential (MMP), a key indicator of severe cellular damage. The MitoNIR dye accumulates in the mitochondria. In apoptotic cells, the NIR stain intensity is decreased due to the collapse of MMP. Cells stained with NIR dye can be visualized with a flow cytometer at red excitation and farred emission (FL4 channel). 
The results of one experiment (representative of three independent determinations) are shown in Figure 3a. The shift in the spectral emission of the dye indicates the dissipation of the MMP. (calibration was performed using $\mathrm{CCCP}$ ). Both psiadin and plectranthone induced a change in the $\Delta \psi \mathrm{m}$. The effect was more pronounced in Hep3B cells.

2.6 Effect of psiadin and plectranthone on NF $\kappa B$ DNA-binding activity

Figure $3 \mathrm{~b}$ shows the measurements for the binding of nuclear extracts of HepG2 and Hep3B cells to immobilized DNA sequences representing the NFKB binding sites. Specific binding was confirmed with the purified $\mathrm{NF}_{\mathrm{B}} \mathrm{B}$ protein included with the kit. Cell extracts treated with DMSO vehicle showed a significant level of binding for both cell extracts. Both drugs significantly inhibited this binding to an approximately similar degree.

\subsection{Measurement of reactive oxygen species generation}

As shown in Figure 3c, neither cell line under control conditions exhibited any observable fluorescence using a ROS detection kit. However, treatment with either psiadin or plectranthone resulted in the detection of intense fluorescence in both cell populations indicating ROS presence. 
(a)

HepG2

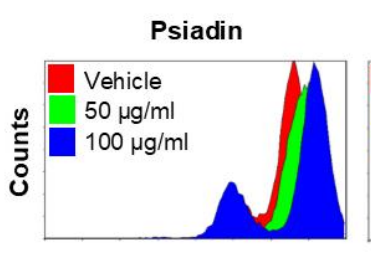

(b)
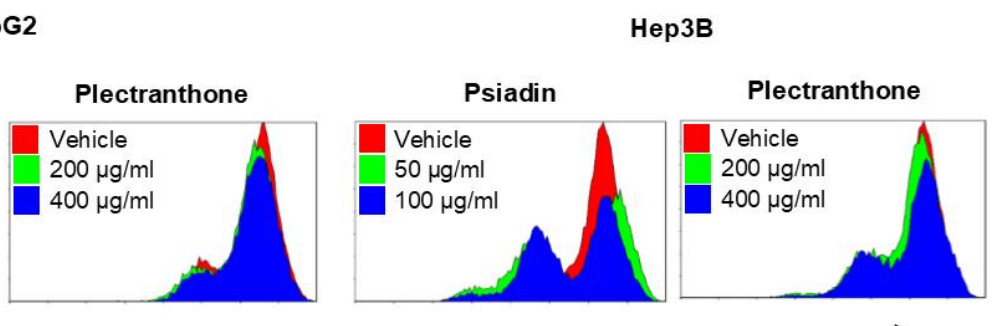

FL4 - H

HepG2
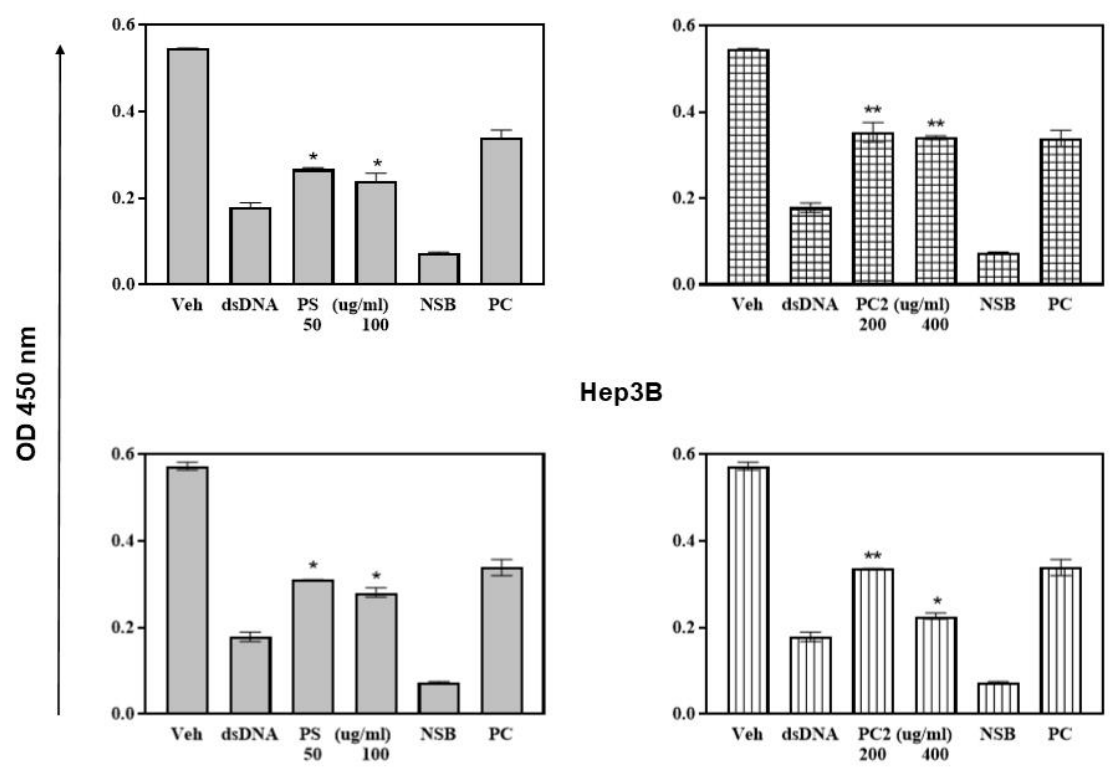

Нер3B

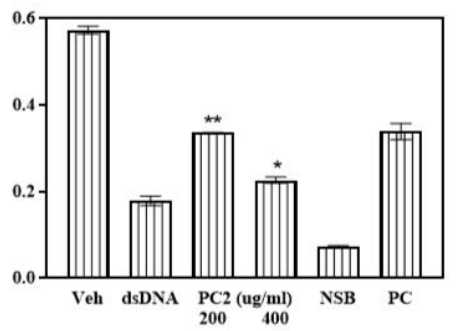

(c)
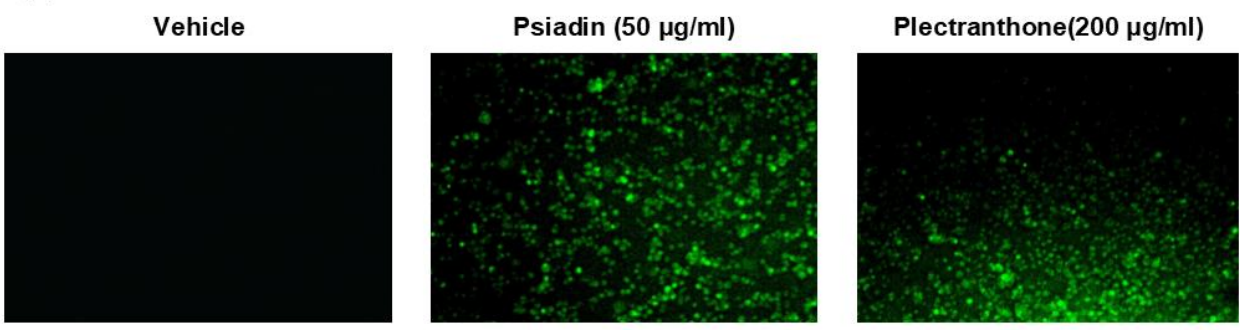

HepG2
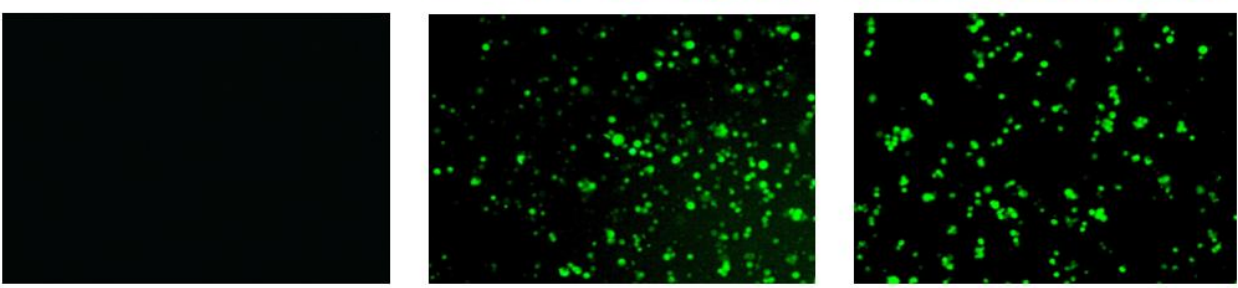

Hep3B

Figure 3. Psiadin and plectranthone induce mitochondrial-mediated apoptosis, inhibit NF-kB, and initiate ROS generation in HepG2 and Hep3B cells. (a) Mitochondrial membrane potential detection by MitoNIR dye staining after treating the cells with the indicated concentrations of each terpene for $24 \mathrm{~h}$. The produced fluorescence intensity was measured by flow cytometry in the FL4-H channel. (b) NFKB DNA-binding activity where cells were treated with the indicated concentrations of psiadin (PS) or plectranthone (PC2) for $24 \mathrm{~h}$. Histobars represent mean \pm SEM of three independent determinations. NSB: non-specific binding, PC: positive control, Veh: vehicle, dsDNA: specific competitor. Drug treatments significantly differ from control/vehicle with $\mathrm{p}<0.01\left(^{*}\right)$ and $\mathrm{p}=0.02\left({ }^{* *}\right)$. (c) ROS generation where HepG2 and Hep3B were treated with the indicated concentrations of each terpene for $48 \mathrm{~h}$, and then examined with inverted immunofluorescent microscope. 


\subsection{Protein expression}

Using western blotting, the levels of various proteins known to be involved in cell cycle regulation and apoptotic processes, and some associated with cell signaling pathways, were measured. We limited this study to psiadin as the most effective of the three compounds under investigation; to one of the two cell lines since they had so far shown broadly similar behavior (Figure 4). Panel A shows the expression of proteins known to be associated with the cell cycle. Psiadin substantially reduced CDK4 in psiadin-treated cells. CDK6 was also lower, though to a lesser extent. Moreover, psiadin increased the level of p-KIP, a CDK interacting protein/kinase inhibitory protein. Panel B shows several pro-apoptotic factors; AIF and BID were unchanged, whereas BAK was increased. Among the caspases tested, no change was seen in Procaspase, Caspase 3 or 8. Cleaved Caspase 9 was either unchanged or lower. Among the anti-apoptotic factors (Panel C), there was a small reduction in CIAP 2, no change in CIAP 1 or MCL a pro-survival member of the BCL2 family, increase in FLIP. We examined a few mitochondrial proteins (Panel D) and did not find much change in SMAC, a very small increase in BCLX, and a large increase in Cyt C. We also looked at the RB protein because of its well-established role as a tumor suppressor and cell cycle regulation (Panel E). There was a significant reduction in the levels of both total and phosphorylated forms of the RB protein. Examples of some essential proteins involved in cell signaling pathways are shown in Panel F. Total and, phosphorylated forms of AKT did not change. Nor did we observe any changes in MEK or p-MEK. Finally, in Panel G, it can be seen that PARP was unchanged. 
Veh PS

\section{A. Cell cycle}
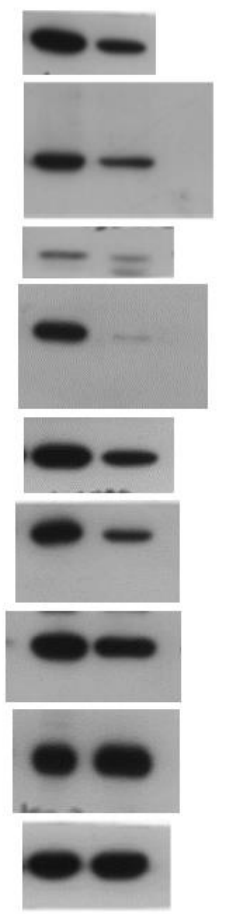

$\beta$-actin

\section{Mitochondrial - associated}

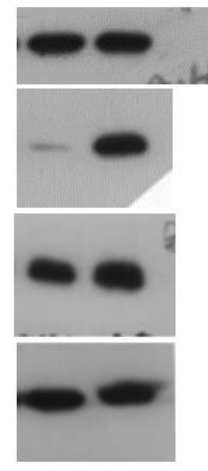

SMAC

Cyt C

BCLX

$\beta$-actin

\section{G. DNA repair}

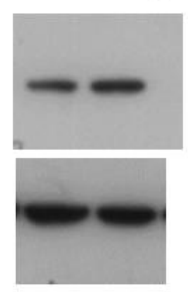

PARP

$\beta$-actin
Veh PS

B. Pro-apoptotic

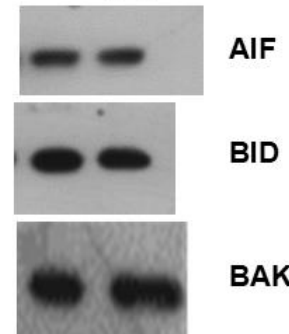

BAK

Procaspase

Caspase-3

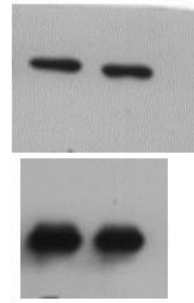

Caspase-8

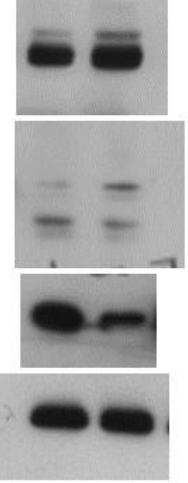

(n)

Caspase-8 cleaved

Caspase-9 cleaved

$\beta$-actin

\section{E. Tumor suppressors}

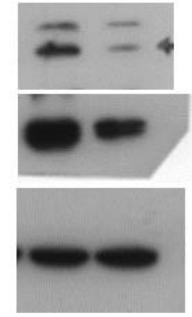

\section{RB}

p-RB

$\beta$-actin

\section{Veh PS}

C. Anti-apoptotic

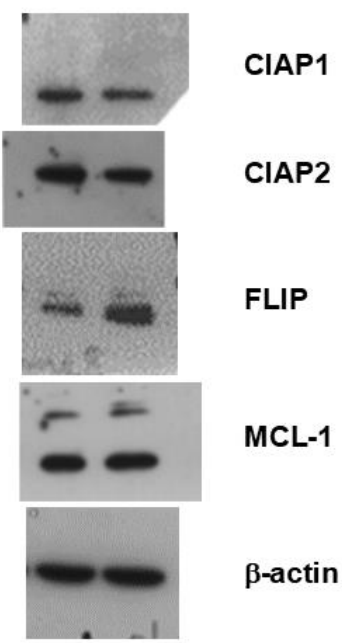

\section{F. Cell signaling}

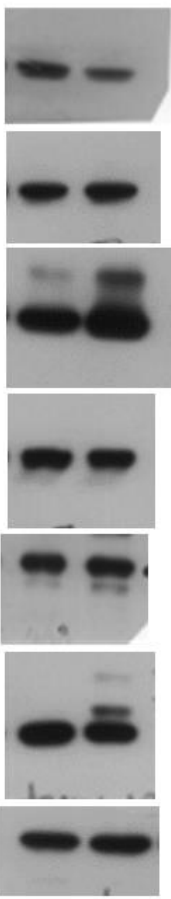

$\beta$-actin

Figure 4. Expression of proteins implicated in various cellular functions measured in HepG2 cells treated with psiadin (PS) or vehicle control (Veh). Protein extracts were electrophoresed on polyacrylamide gels, electroblotted onto PVDF membranes, cut into thin strips, and incubated with appropriate primary antibodies, followed by secondary antibodies and visualized by autoradiography with ECL reagents as described in Methods. For each group of proteins, KIP was used as loading control. Blots are representative of at least three independent experiments yielding very similar results.

\section{Discussion}


Standard cancer chemotherapy relies on a limited number of favored drugs to inhibit various aspects of cancer cell growth. However, both the substantial 'collateral damage' to normal tissues due to lack of specificity as well as the emergence of intrinsic or acquired drug resistance [24] presents a serious therapeutic problem. The need for new drugs has prompted studies evaluating possible anticancer agents in natural resources. Natural products with diverse bioactivities are becoming an important source of novel agents with pharmaceutical potential. The potential for plant extracts to act as anticancer agents is due to their abilities to inhibit tumor growth, angiogenesis, and metastasis with few side effects [2]. In this study we isolated, confirmed the identities of three terpenes; psiadin, plectranthone and saudinolide, and tested them against two commonly used hepatic carcinoma cell lines.

The designated plants were collected, authenticated and voucher specimens were processed appropriately. Their coarsely powdered aerial parts were extracted and purified as detailed above.

Psiadin was isolated as colorless needles. The IR spectrum of psiadin showed absorption bands for carbonyl and hydroxyl groups. The presence of a ketone carbonyl group was further supported from the ${ }^{13} \mathrm{C}$ NMR spectra, which exhibited 20 carbon resonances; one of them is a ketone carbonyl, which resonated as a singlet at $\delta$ 212.7. Its molecular formula was determined as $\mathrm{C}_{20} \mathrm{H}_{30} \mathrm{O}_{3}$ based on the ion peak at $m / z 319.3400[\mathrm{M}+1]^{+}$. The NMR spectral data (Table 1 ) showed signals characteristic of exocyclic methylene group ( $\delta \mathrm{H} 4.82,4.76$, each resonated as a singlet and integrated for $1 \mathrm{H}, \mathrm{H}-17 ; \delta \mathrm{c}$ $103.6, \mathrm{t})$ and a single methyl group ( $\delta_{\mathrm{H}} 1.06, \mathrm{~s}, 3 \mathrm{H}, \mathrm{H}-20 ; \delta \mathrm{c} 19.3$, q). Additionally, the presence of two hydroxymethyl groups was confirmed. One group $(\mathrm{H}-18)$ resonated at $\delta \mathrm{H} 3.85$ as a singlet and integrated for $2 \mathrm{H}(\delta \subset 70.9, \mathrm{t})$, and the other one $(\mathrm{H}-19)$ resonated at $\delta \mathrm{H} 3.74,1 \mathrm{H}, \mathrm{d}, J=10.5 \mathrm{~Hz}$, and at $\delta_{\mathrm{H}} 3.54,1 \mathrm{H}, \mathrm{d}, J=10.5 \mathrm{~Hz}(\delta \mathrm{c} 65.4, \mathrm{t})$. These data are consistent with a kaur-16-ene diterpene structure and identical to those previously reported for psiadin [25].

Plectranthone was isolated as colorless prisms. The molecular formula of this compound was determined as $\mathrm{C}_{19} \mathrm{H}_{28} \mathrm{O}_{5}$ on the basis of the ion peak at $m / z 277.2827$ [M $\left.-\mathrm{CH}_{3} \mathrm{COOH}+1\right]^{+}$and the NMR data. Its IR spectrum showed absorption bands for two different carbonyl functions, an $\alpha, \beta$ unsaturated ketone $\left(1670 \mathrm{~cm}^{-1}\right)$ and an ester band $\left(1725 \mathrm{~cm}^{-1}\right)$. The ${ }^{13} \mathrm{C}$ NMR spectrum (Table 1$)$ showed 19 carbon resonances, including five quartets, four triplets, five doublets, and five singlets.

The presence of an isopropyl group was indicated by the fact that two of the methyl carbons resonated at $\delta c 21.1$ and 21.2 and correlated with two doublets, each of which integrated for three protons and resonated at $\delta_{\mathrm{H}} 0.88(\mathrm{~J}=6.7 \mathrm{~Hz})$ and $0.86(J=6.7 \mathrm{~Hz})$. The two olefinic carbons of the $\alpha, \beta-$ unsaturated ketone resonated as a singlet ( $\delta$ c 158.0, C-4) and a doublet ( $\delta$ c 128.7, C-3), with the carbonyl carbon absorbing at $\delta$ 198.4. The ${ }^{1} \mathrm{H}$ NMR spectrum of this compound exhibited two AB coupling systems. One of these was due to the protons of the isolated methylene group at C-1 and the other one was ascribed to the pair of protons at C-14. Other 2D NMR data confirmed the identity of this compound to be the eudesmane sesquiterpene plectranthone [13].

On the other hand, saudinolide was isolated as colorless granules. This compound, possessing the molecular formula $\mathrm{C}_{20} \mathrm{H}_{20} \mathrm{O}_{8}$, was found to have a $\gamma$-lactone $\left(\lambda_{\max } 1780 \mathrm{~cm}^{-1} ; \delta c 174.7\right)$, a $\delta$-lactone $\left(\lambda_{\max } 1720 \mathrm{~cm}^{-1} ; \delta \mathrm{c} 172.9\right)$, and a mono-substituted furan ring. Additionally, ${ }^{1} \mathrm{H}$ and ${ }^{13} \mathrm{C}$ NMR data (Table 1$)$ indicated the presence of a hydroxyl group at $\mathrm{C}-5\left(\lambda_{\max } 3520 \mathrm{~cm}^{-1} ; \delta \subset 72.5, \mathrm{C}\right)$, a disubstituted double bond at C-14(15) ( $\left.\delta c_{-114} 126.2, \delta c-15132.3\right)$, and an oxide bridge at C-7(10) ( $\delta \mathrm{c}-7$ 108.4; $\delta \mathrm{c}-10$ 100.6). Furthermore, a COSY experiment suggested the presence of the system $-\mathrm{CH}=\mathrm{CHCH}(\mathrm{O})-$, and this was confirmed by the HSQC experiment, which showed signals at $(\delta \mathrm{c} 73.0(\mathrm{CH} 2), 44.3(\mathrm{C}), 126.2(\mathrm{CH})$, 
$132.3(\mathrm{CH})$, and $48.8(\mathrm{C})$ assigned to C-1, C-13, C-14, C-15, and C-16, respectively. C-10 showed a high degree of oxygenation as indicated by the characteristic resonances at $\delta_{\mathrm{H}} 5.93(\mathrm{~s})$ and $\delta \mathrm{c} 100.6(\mathrm{CH})$. This last piece of information, together with the fact that the C-7 signal occurred at $\delta \mathrm{c} 108.4$, suggested the gross structure of saudinolide. Other NMR data were in accordance with those previously assigned to the diterpene saudinolide [12].

The results presented in this study showed that none of the tested terpenes had appreciable toxicity against normal human cells. Saudinolide, at the concentrations tested, was also relatively ineffective against the cancer cells and was not further considered. Psiadin and plectranthone showed appreciable activity against both cancer lines, with psiadin being the more effective killing agent. To put this into more therapeutic context, we compared the effect of the two terpenes with several agents that are currently used in clinical practice. In both cases they compared very favorably in their efficacy, particularly psiadin, showing itself to be significantly more effective than standard chemotherapy drugs such as DOX and 5FU.

To determine how these terpenes may exert their inhibitory actions, we looked at several selected cellular processes involved in proliferation/cell death and established cancer progression hallmarks. Examination of the cell cycle stage showed that psiadin and plectranthone had different effects on the two cell lines. In HepG2 cells, psiadin caused cell cycle arrest in both the G1/G0 and G2/M phases, thereby preventing cells from initiating DNA replication needed for cell division. In Hep3B cells, the blockade was seen only in the G2/M phase suggesting differences in cellular response to this compound. Plectranthone did not seem to have any significant degree of influence on the cell cycle in either cell line, suggesting that its effect on proliferation was mediated differently from psiadin. Eukaryotic cells are dependent upon the production of various cyclin proteins, which through interaction with corresponding cyclin-dependent kinases facilitate cells' progression through cell cycle checkpoints, which ultimately leads to cell division. Mitogenic signals, such as those mediated through the ERK/MEK pathway, result in the association of cyclins D with CDK4/6 leading to increased phosphorylation and, thereby, deactivation of the tumor suppressor RB protein [26]. This then relieves its repression of transcription factor E2F, allowing it to transcribe cyclins $\mathrm{A}$ and $\mathrm{E}$, combining with CDK2 to take the cell through the G1 and G2/M checkpoints. We observed a general decrease in all the cyclins that were measured as well as in CDK4 in HepG2 cells treated with psiadin, indicating complete disruption of the cycling process. There was a small reduction in CDK2 which is thought to drive cells' progression into S and M phase [27]. An interacting factor p-KIP [28] was increased by psiadin. This is known to inhibit the interaction of CDK4/6 with cyclin D which complex is involved in RB phosphorylation. It may also block CDK2 interaction with cyclin E which allows cells to exit from G1 into G0.

Failure to progress through cell cycle checkpoints is thought to lead to apoptosis, and as with other natural products $[29,30]$ this seems to be the consequence of psiadin exposure. Consistent with the MTT assay data, the viability of both cell lines was drastically reduced with a concurrent increase in cells undergoing both early and late phases of apoptosis as well as direct necrosis. Apoptosis is often divided into the extrinsic and intrinsic or mitochondrial pathways [31] involving activation of several caspases in the formation of an apoptosome, [32] also involving BCL2 family members such as BAX and BAK and release of pro-apoptotic proteins including cyt C [33]. Thus, psiadin in HepG2 cells elevated BCLX and BAK and substantially increased cyt C but surprisingly did not appear to increase caspases. Psiadin also did not affect the level of poly (ADP-ribose) polymerase (PARP), 
which is often involved in DNA repair. The mitochondrial membrane potential $(\Delta \Psi \mathrm{m})$, generated by proton pumps (Complexes I, III and IV), is critical for maintaining the physiological function of the respiratory chain to generate ATP [34]. Opening the mitochondrial permeability transition pore (MPTP) leads to the fairly catastrophic collapse of the $\Delta \Psi \mathrm{m}$ and subsequent release of cyt $\mathrm{C}$ into the cytosol, which in turn triggers other downstream events in the apoptotic cascade as mentioned above. Our data show that both psiadin and plectranthone mimicked the effects of a mitochondrial uncoupler (4-(trifluoromethoxy)phenyl) carbonohydrazonoyl dicyanide) in producing some reduction in the $\Delta \Psi \mathrm{m}$ in both cell lines, indicating that these compounds induce end-stage mitochondrial dysfunction. This has been observed with a number of common anti-cancer drugs [35]. The effect was most pronounced in HepB3 cells with psiadin. In HepG2 cells, psiadin caused increased production of mitochondrial proteins Cyt C and BCLX but not of AIF or BID, which are other BCL2 pro-apoptotic proteins.

It has been reported that resistance to apoptosis may be dependent on activation of NF- $\mathrm{KB},[36]$ via its many target genes [37], and its action in preventing mitochondrial-mediated apoptosis through neutralization of ROS. Consistent with this are our findings that both terpenes, psiadin and plectranthone, which cause apoptosis, also significantly reduced NF- $\kappa B$ binding of nuclear extracts to a consensus DNA response element for both cell lines. In addition to this, we also observed a very significant production of ROS induced by both drugs and in both cell lines. In this regard, we observed a small psiadin-induced decrease in CIAP 2 known to be NF- $\mathrm{KB}$ regulated. Among other anti-apoptotic molecules, there was no change in FLIP or MCL.

We observed no change in the survival factor AKT. Similarly, there was no effect on the levels of the ERK pathway intermediate MEK or of p38.

\section{Materials and Methods}

\subsection{Plant material}

The aerial parts of three plants; Psiadia arabica Jaub. et Spach. (known locally as "Tabbak"), Plectranthus cylindraceus Hochst. ex Benth (known locally as "Al-Shar") and Cluytia richardiana L. (known locally as "Sa'eer") were collected from Wadi Al Uss, near Abha, Saudi Arabia between March and April, 2012. The plant identities were authenticated by Dr. Sultan-ul-Abdeen and voucher specimens (\# 10331, 10352 and 10362, respectively) were deposited at the herbarium of the College of Pharmacy, King Saud University, Riyadh, Saudi Arabia. All plants names have been checked with http://www.theplantlist.org.

\subsection{Extraction and isolation}

Psiadia arabica. The powdered aerial parts $(2 \mathrm{~kg})$ were exhaustively extracted with chloroform in a Soxhlet for $72 \mathrm{~h}$. Evaporation in vacuo gave a $260 \mathrm{~g}$ greenish residue that was partitioned between 3 $\mathrm{L}$ chloroform and water $(3 \times 1 \mathrm{~L})$. The chloroform fraction, after evaporation, was partitioned between $10 \%$ aqueous methanol ( $2 \mathrm{~L}$ ) and 3 portions each of $1 \mathrm{~L}$ of $n$-hexane. The combined hexane layers were washed with $100 \mathrm{ml}$ of the methanol layer. Evaporation of the combined methanol layers gave $185 \mathrm{~g}$ as a gummy residue. This residue was chromatographed, in portions, on silica gel columns (each was $550 \mathrm{~g}, 25 \times 7.5 \mathrm{~cm}$ ) using $\mathrm{CHCl}_{3}-\mathrm{MeOH}, 4: 1$, yielding $1380 \mathrm{mg}$ of the impure diterpene psiadin, which upon crystallization from methylene chloride-EtOAc gave $813 \mathrm{mg}$ of pure psiadin as colorless needles. 
Plectranthus cylindraceus. The dried powdered aerial parts $(1.12 \mathrm{~kg})$ were percolated at room temperature with $95 \% \mathrm{EtOH}(3 \times 4 \mathrm{~L})$, and the extract was evaporated in vacuo to leave $22 \mathrm{~g}$ of residue, which was chromatographed over silica gel $(500 \mathrm{gm}, 4 \times 130 \mathrm{~cm})$, using increasing concentrations of EtOAc in $n$-hexane as an eluent, to yield, after crystallization from EtOAc-petroleum ether, $1400 \mathrm{mg}$ of plectranthone as colorless prisms.

Cluytia richardiana. The dried powdered aerial parts $(1.6 \mathrm{~kg})$ were percolated successively at room temperature in petroleum ether $\left(60-80^{\circ} \mathrm{C}\right)$ and then in EtOAc. Upon drying in vacuo, the EtOAc fraction afforded $65 \mathrm{~g}$ of greenish-white precipitate, which was filtered off to yield $26 \mathrm{~g}$ of the precipitate. This precipitate was subjected to chromatographic purification over flash silica gel (2.6 $\mathrm{kg})$. Elution with petroleum ether $\left(60-80{ }^{\circ} \mathrm{C}\right)$-EtOAc (8.5:1.5) yielded $560 \mathrm{mg}$ saudinolide. Crystallization from EtOAc-petroleum ether afforded $450 \mathrm{mg}$ as colorless granules.

\subsection{Terpenes identification}

Melting points were determined in open capillary tubes using a Mettler 9100 electrothermal melting point apparatus and were uncorrected. IR spectra were recorded using a JASCO FTIR-4100 spectrophotometer. UV spectra were measured in MeOH using a UV-160 IPC UV-visible dual-beam spectrophotometer. The ${ }^{1} \mathrm{H}$ and ${ }^{13} \mathrm{C}$ NMR spectra were obtained on a Bruker Advance II $600-\mathrm{MHz}$ spectrometer operating at 600 and $150 \mathrm{MHz}$, respectively. Both ${ }^{1} \mathrm{H}$ and ${ }^{13} \mathrm{C}$ NMR spectra were recorded in $\mathrm{CDCl}_{3}$, and the chemical shift values were expressed in $\delta(\mathrm{ppm})$ relative to the internal standard TMS. For the ${ }^{13} \mathrm{C}$ NMR spectra, spectral editing was determined by DEPT. 2D NMR data were obtained using the standard pulse sequence of the Bruker 600 for COSY, HSQC and HMBC. High resolution ESMS were obtained using a double-focusing magnetic sector mass spectrometer (GC-MS DFS, Thermo).

\subsection{Cell lines}

Human hepatic carcinoma cells Hep3B and HepG2, were obtained from the American Type Culture Collection (ATCC; VA, USA). Theywere cultured in 90\% Leibovitz's L15 medium supplemented with $10 \%$ heat-inactivated fetal bovine serum (FBS) and grown at $37^{\circ} \mathrm{C}$ in an incubator with $5 \% \mathrm{CO}_{2}$ atmosphere.

\subsection{Chemicals and reagents}

Trypsin, Leibovitz's L-15 and EMEM medium, FBS, and penicillin/ streptomycin solution (100×) were obtained from Mediatech (Herndon, VA, USA). Annexin V-FITC apoptosis detection kit was obtained from BD Hoffmann-La Roche Inc. (NJ, USA). DNA extraction kit was obtained from Beckman \& Coulter (FL, USA). Nuclear/cytosol fractionation kit was obtained from BioVision, Inc. (Mountain View, CA, USA). Antibodies used in this study and their sources are listed in the Supplementary Table. All other reagents were purchased from Sigma Chemicals (MO, USA).

\subsection{MTT assay}

Cell viability was determined at various times (24-144 h) using MTT (3-(4,5-Dimethyl-2thiazolyl)-2,5-diphenyl-2H-tetrazolium bromide) assay, which is based on the conversion of MTT to formazan crystals by mitochondrial dehydrogenases [38]. Briefly, cells were seeded at $27 \times 10^{3}$ cells/well in 96-well plates and incubated at $37^{\circ} \mathrm{C}$ for $24 \mathrm{~h}$. The cells were then treated with various 
concentrations of each terpene under investigation (or $0.2 \%$ DMSO vehicle for control condition) for various times (24-144h). MTT solution $(5 \mathrm{mg} / \mathrm{ml})$ was added to the incubated cells $(20 \mu \mathrm{l} /$ well); the cells were then incubated for another $4 \mathrm{~h}$ and the medium was discarded. DMSO $(200 \mu \mathrm{l})$ was added to each well, and the absorbance measured in a micro-plate reader at $492 \mathrm{~nm}$. All samples were assayed in triplicate in three independent experiments. The results (mean $\pm \mathrm{SEM}$ ) are expressed as \% cytotoxicity; by dividing the densitometric readings for the drug treated conditions by that of the DMSO treated control.

In a separate series of experiments, the effect of each of the terpenes on the cancer cell lines was compared with camptothecin (CPT), 5-fluorouracil (5FU), doxorubicin (DOX) and ellipticine (ELP) over $72 \mathrm{~h}$ of drug exposure.

As we later determined that the terpenes had effects on mitochondrial function and therefore might affect the MTT assay which depends on a reaction occurring within the mitochondria we also used the MTX assay as well as doing direct cell counting for a number of drug treated samples and obtained similar results. Therefore, we concluded that the reaction involving MTT was not affected.

\subsection{Colony forming assay}

Briefly, cancer cells $\left(10^{5} /\right.$ well) were plated in a 24-well plate and incubated at $37^{\circ} \mathrm{C}$ for $18 \mathrm{~h}$. Thereafter, the cells were treated with serial doses of the test compounds (or DMSO vehicle for controls) and incubated at $37^{\circ} \mathrm{C}$ for $24 \mathrm{~h}$. After that, cells were collected by trypsinization, washed with Hank's Balanced Salt Solution (HBSS), counted and plated in 24-well plates at 500 cells/well, and incubated at $37^{\circ} \mathrm{C}$ for $10-14$ days. The resultant colonies were washed with cold phosphate-buffered saline (PBS), fixed with $100 \%$ methanol, and stained with $0.1 \%$ crystal violet. The colonies were counted using an inverted microscope [39].

\subsection{Cell cycle analysis}

The distribution of cell-cycle phases $\left(\mathrm{G}_{0} / \mathrm{G}_{1}, \mathrm{~S}\right.$ and $\left.\mathrm{G}_{2} / \mathrm{M}\right)$ was determined using flow cytometry by measuring the DNA content of nuclei labeled with propidium iodide as described previously [40]. Briefly the cancer cell lines were plated at $2.5 \times 10^{5} \mathrm{cells} / \mathrm{ml}$ in 24 -well plates and incubated at $37^{\circ} \mathrm{C}$ for $18 \mathrm{~h}$. The cells were then treated with psiadin $(100-400 \mu \mathrm{g} / \mathrm{ml})$ and plectranthone $(200-800 \mu \mathrm{g} / \mathrm{ml})$ or DMSO vehicle for $24 \mathrm{~h}$. Cells were collected by trypsinization, washed with cold PBS and counted. Cells were processed using a DNA-prep kit (Beckman \& Coulter, USA). For this end, the cells were treated with a cell-membrane permeabilizing agent followed by propidium iodide and RNase. The samples were incubated at room temperature for $15 \mathrm{~min}$ before analysis by flow cytometry (FC500, Beckman \& Coulter, USA). The percentages of cells in different cell cycle phases were calculated using the statistical software package, advanced DNA cell-cycle software from Phoenix Flow System (San Diego, USA).

\subsection{Apoptosis assay}

Induction of apoptosis was determined by annexin V-FITC apoptosis detection kit (BD Hoffmann La Roche Inc, USA) according to the manufacturer's instructions. Briefly, cancer cells were plated $\left(2.5 \times 10^{5}\right.$ cells $\left./ \mathrm{ml}\right)$ in 24 -well plate and incubated at $37^{\circ} \mathrm{C}$ for $18 \mathrm{~h}$. Following treatment with psiadin $(100-400 \mu \mathrm{g} / \mathrm{ml})$, plectranthone $(200-800 \mu \mathrm{g} / \mathrm{ml})$ or DMSO vehicle for $24 \mathrm{~h}$, cells were re- 
suspended in $100 \mu \mathrm{l}$ of annexin V fluorescein and propidium iodide in HEPES buffer. Following incubation in darkness at room temperature for $15 \mathrm{~min}$, cells were analyzed by flow cytometry.

\subsection{Measurement of mitochondrial membrane potential}

To determine whether mitochondrial damage occurs as an early event in psiadin or plectranthone-induced apoptosis, changes in mitochondrial membrane potential $(\Delta \Psi \mathrm{m})$ were measured using flow cytometry with NIR Mitochondrial Membrane Potential Assay Kit (Ab112149) from Abcam (UK). Cancer cells were plated at $2.5 \times 10^{5}$ cells $/ \mathrm{ml}$ in 24 -well plates at $37^{\circ} \mathrm{C}$ for $18 \mathrm{~h}$ followed by treatment with psiadin $(50,100 \mu \mathrm{g} / \mathrm{ml})$ and plectranthone $(200,400 \mu \mathrm{g} / \mathrm{ml})$ for $24 \mathrm{~h}$. The adherent cells were gently detached with $0.5 \mathrm{mM}$ EDTA to keep them intact and washed once with serum-containing media prior to incubation with NIR dye loading solution. MitoNIR Dye ( $5 \mu \mathrm{l})$ was added and the cells incubated at $37^{\circ} \mathrm{C}$ for $15-30 \mathrm{~min}$ then centrifuged at $1000 \mathrm{rpm}$ for $4 \mathrm{~min}$, resuspended in $1 \mathrm{ml}$ of assay buffer and fluorescence intensity monitored in the FL4 channel (Ex / Em = 635/660) using a flow cytometer gated on the cells of interest. Experimental conditions were standardized using the mitochondrial uncoupler, ((3-chlorophenyl)hydrazono)malononitrile, (CCCP) from Abcam (Ab141229) as a positive control.

\subsection{NF $\kappa B$ DNA-binding activity}

Cancer cells were plated at $2.5 \times 10^{5}$ cells $/ \mathrm{ml}$ into 24 -well plates at $37^{\circ} \mathrm{C}$ for $18 \mathrm{~h}$, then treated with psiadin $(50,100 \mu \mathrm{g} / \mathrm{ml})$, plectranthone $(200,400 \mu \mathrm{g} / \mathrm{ml})$ or DMSO vehicle for $24 \mathrm{~h}$. Cells were harvested and nuclear extracts prepared using a cytosol/nuclear fractionation kit from BioVision (CA, USA) as per the manufacturer's instructions. NF-КB DNA-binding activity was determined using an NF-kBp65 Transcription Factor Assay Kit (ab133112; Abcam, UK) which utilizes a 96-well plate with a specific DNA sequence containing the NF- $\mathrm{\kappa B}$ response element immobilized onto the bottom of the wells. Following the manufacturer's protocol, nuclear cell extracts were added to wells and incubated with shaking for $1 \mathrm{~h}$ at room temperature. Following washing 5 times with wash buffer, NF-kB specific primary antibody was added to wells for $1 \mathrm{~h}$, subsequent washing as above, then addition of goat anti-rabbit HRP conjugated secondary antibody for another $1 \mathrm{~h}$. After further extensive washing and incubation for 15-45 min with developer solution, absorbance at $450 \mathrm{~nm}$ was determined in a plate reader.

\subsection{Measurement of reactive oxygen species generation}

Cancer cells were plated at $2.5 \times 10^{5}$ cells $/ \mathrm{ml}$ into 24 -well plates at $37^{\circ} \mathrm{C}$ for $18 \mathrm{~h}$. Media was removed and cells gently washed with HBSS (2-3 times) followed by addition of $100 \mu \mathrm{l}$ of $1 \times 22^{\prime} 7^{\prime}$ dichlorofluorescein diacetate (DCFH-DA) (Sigma, USA) in PBS for 30-60 min in the dark at 37०C. Solution was then removed and cells were washed with HBSS (2-3 times). The DCFH-DA loaded cells were then treated with psiadin $(50,100 \mu \mathrm{g} / \mathrm{ml})$, plectranthone $(200,400 \mu \mathrm{g} / \mathrm{ml})$ or DMSO vehicle for $24 \mathrm{~h}$. Cells were then examined by inverted fluorescence microscopy.

\subsection{Western blot analysis}

Cancer cells were cultured in 6 well plates $\left(5 \times 10^{5}\right.$ cells $\left./ \mathrm{ml}\right)$ to approximately $75-80 \%$ confluency and then treated with psiadin $(75 \mu \mathrm{g} / \mathrm{ml})$ or DMSO vehicle. After $24 \mathrm{~h}$ exposure cells were harvested and recovered by centrifugation for $5 \mathrm{~min}$ at $1000 x \mathrm{~g}$. Fresh cell pellets were washed with PBS and 
then re-suspended into $300 \mu \mathrm{l}$ of homogenization buffer containing $50 \mathrm{mM}$ HEPES, $50 \mathrm{mM} \mathrm{NaCl}, 5$ mM EDTA, $1 \%$ Triton X-100, $10 \mu \mathrm{g} / \mathrm{ml}$ leupeptin, $10 \mu \mathrm{g} / \mathrm{ml}$ aprotinin and $100 \mu \mathrm{g} / \mathrm{ml}$ PMSF. The Pierce BCA protein assay dye reagent (Pierce, Rockford, USA) was used to determine protein concentration in the cell lysate. About $30 \mu \mathrm{g}$ of protein was mixed with an equal volume of $2 \times$ sample loading buffer containing $100 \mathrm{mM}$ Tris-Cl (pH 6.8), 4\% (w/v) SDS, 0.2\% (w/v) bromophenol blue, 20\% (v/v) glycerol and $200 \mathrm{mM}$ dithiothreitol, and heated at $90^{\circ} \mathrm{C}$ for $10 \mathrm{~min}$. Lysates were loaded onto $10 \%$ SDS-polyacrylamide gels and electrophoresed at $150 \mathrm{~V}$ for $1 \mathrm{~h}$. Proteins were then transferred onto a PVDF membrane and, using the molecular weight markers lane as a guide, cut into narrow strips (in order to economize on antisera) in the size range of the expected protein to be detected. Each strip was then treated with $2 \%$ BSA for $1 \mathrm{~h}$ before being incubated overnight at $4{ }^{\circ} \mathrm{C}$ with various primary antibodies (listed in Supplementary Table). After removal of the antisera the membrane was washed and subsequently incubated with anti-HRP-conjugated secondary antibody (1:500) for $1 \mathrm{~h}$, and signals developed with Super Signal ECL and visualized with Kodak X-ray film. Bands were quantified by densitometry and intensity calculated proportional to that obtained for $\beta$ actin on the same blot.

\subsection{Statistical analysis}

Differences between mean values of tested terpenes was analyzed by the student's t-test or oneway ANOVA followed by Bonferroni post-hoe test using GraphPad Prism 8. P $<0.05$ was considered statistically significant.

\section{Conclusions}

In summary, we have examined the anti-cancer potential of three terpenes purified from natural products. Saudinolide was not useful, and plectanthrone was effective in some processes but only at very high concentrations. Psiadin, on the other hand, could be a very promising lead compound. It showed little activity against normal cells but was significantly more effective at killing two hepatic cancer cell lines than several currently used chemotherapeutic drugs. We examined several processes commonly associated with cancer cell metabolism but were unable to pinpoint any specific cellular target so that it may have a wide range of activity. Although, cytotoxic agents often result in many changes that are secondary to their primary effect, however, we did observe disruption of a number of specific cellular pathways, most prominently cell cycle proteins, stimulation of mitochondrially mediated apoptotic pathways, very pronounced induction of ROS, and inhibition in expression and function of the RB protein. In future experiments it would be worthwhile to examine genome-wide expression and perform whole proteome analysis of psiadin-treated cells. It will also be necessary to test the effects of psiadin on other cell lines to determine its general applicability. Also, in vivo animal studies, which were beyond the present investigations' scope, would be the next step to see whether psiadin is active against tumors, having established its effects in vitro.

Supplementary Materials: Table S1: Antibodies used in this project along with their target proteins and sources.

Author Contributions: Conceptualization, K.Y.O. and M.S.A.; methodology, K.Y.O, M.S.A., R.A. and Y.A.L.; validation, K.Y.O., M.S.A. and Y.A.L.; formal analysis, K.Y.O. and Y.A.L.; investigation, K.Y.O., M.S.A. and Y.A.L.; resources, K.Y.O. and M.S.A.; data curation, K.Y.O., M.S.A. and Y.A.L.; writing-original draft preparation, K.Y.O. and Y.A.L.; writing - review and editing, K.Y.O., M.S.A. and Y.A.L.; visualization, K.Y.O.; supervision, K.Y.O.; project administration, K.Y.O.; funding acquisition, K.Y.O. All authors have read and agreed to the published version of the manuscript.

Funding: This research was funded by of Kuwait University Research sector, grant number PC01/12. and grant SRUL02/13 to the Research Unit for Genomics, Proteomics and Cellomics Studies. The spectral analyses were 
obtained at the Research Sector Project Unit (RSPU), Faculty of Science, Kuwait University, supported by Grant numbers GS01/01 and GS01/03.

Acknowledgments: Ms. Samar Faggal is acknowledged for her excellent technical assistance with the protein expression analysis.

Conflicts of Interest: The authors declare no conflict of interest. The funders had no role in the design of the study; in the collection, analyses, or interpretation of data; in the writing of the manuscript, or in the decision to publish the results.

\section{References:}

1. American Cancer Society Global Cancer Facts and Figure. 2020; pp https://www.cancer.org/research/cancer-facts-statistics/global.html

2. Newman, D. J.; Cragg, G. M., Natural Products as Sources of New Drugs over the Nearly Four Decades from 01/1981 to 09/2019. J Nat Prod 2020, 83 (3), 770-803.

3. Ulbricht, C. E.; Chao, W., Phytochemicals in the oncology setting. Curr Treat Options Oncol 2010, 11 (3-4), 95-106.

4. Cragg, G. M.; Pezzuto, J. M., Natural Products as a Vital Source for the Discovery of Cancer Chemotherapeutic and Chemopreventive Agents. Med Princ Pract 2016, 25 Suppl 2, 41-59.

5. Lee, K. W.; Bode, A. M.; Dong, Z., Molecular targets of phytochemicals for cancer prevention. Nat Rev Cancer 2011, 11 (3), 211-8.

6. Tan, A. C.; Konczak, I.; Sze, D. M.; Ramzan, I., Molecular pathways for cancer chemoprevention by dietary phytochemicals. Nutr Cancer 2011, 63 (4), 495-505.

7. Mates, J. M.; Segura, J. A.; Alonso, F. J.; Marquez, J., Anticancer antioxidant regulatory functions of phytochemicals. Curr Med Chem 2011, 18 (15), 2315-38.

8. Neergheen, V. S.; Bahorun, T.; Taylor, E. W.; Jen, L. S.; Aruoma, O. I., Targeting specific cell signaling transduction pathways by dietary and medicinal phytochemicals in cancer chemoprevention. Toxicology 2010, 278 (2), 229-41.

9. Karikas, G. A., Anticancer and chemopreventing natural products: some biochemical and therapeutic aspects. J BUON 2010, 15 (4), 627-38.

10. Mossa, J. S., Medicinal Plants of Saudi Arabia. King Saud University Press: Saudi Arabia, 2000.

11. Mossa, J. S.; El-Denshary, E. S. M.; Hindawi, R.; Ageel, A. M., The Hypoglycaemic Effect of Saudin. International Journal of Crude Drug Research 1988, 26 (2), 81-87.

12. Mossa, J. S.; Muhammad, I.; Al-Yahya, M. A.; Mirza, H. H.; El-Feraly, F. S.; McPhail, A. T., Five New Modified 6,7-Secolabdane Diterpenoids from Cluytia richardiana. Journal of Natural Products 1996, 59 (3), $224-$ 231.

13. Orabi, K. Y.; Mossa, J. S.; Muhammed, I.; Alloush, M. H.; Galal, A. M.; El-Feraly, F. S.; McPhail, A. T., New eudesmane sesquiterpenes from Plectranthus cylindraceus. J Nat Prod 2000, 63 (12), 1665-8.

14. El-Domiaty, M. M.; El-Feraly, F. S.; Mossa, J. S.; McPhail, A. T., Diterpenes from Psiadia arabica. Phytochemistry 1993, 34 (2), 467-471.

15. Mahadeo, K.; Grondin, I.; Kodja, H.; Soulange Govinden, J.; Jhaumeer Laulloo, S.; Frederich, M.; Gauvin-Bialecki, A., The genus Psiadia: Review of traditional uses, phytochemistry and pharmacology. J Ethnopharmacol 2018, 210, 48-68.

16. Aumeeruddy-Elalfi, Z., Antimicrobial, antibiotic potentiating activity and phytochemical profile of essential oils from exotic and endemic medicinal plants of Mauritius. Industrial crops and products 2015, v. 71, pp. 197-204-2015 v.71. 
17. Govinden-Soulange, J.; Magan, N.; Gurib-Fakim, A.; Gauvin, A.; Smadja, J.; Kodja, H., Chemical composition and in vitro antimicrobial activities of the essential oils from endemic Psiadia species growing in mauritius. Biol Pharm Bull 2004, 27 (11), 1814-8.

18. Fortin, H.; Vigor, C.; Lohezic-Le Devehat, F.; Robin, V.; Le Bosse, B.; Boustie, J.; Amoros, M., In vitro antiviral activity of thirty-six plants from La Reunion Island. Fitoterapia 2002, 73 (4), 346-50.

19. Robin, V.; Boustie, J.; Amoros, M.; Girre, L., In-vitro Antiviral Activity of Seven Psiadia Species, Asteraceae: Isolation of Two Antipoliovirus Flavonoids from Psiadia dentata. Pharmacy and Pharmacology Communications 1998, 4 (1), 61-64.

20. Jonville, M. C.; Kodja, H.; Humeau, L.; Fournel, J.; De Mol, P.; Cao, M.; Angenot, L.; Frederich, M., Screening of medicinal plants from Reunion Island for antimalarial and cytotoxic activity. J Ethnopharmacol 2008, 120 (3), 382-6.

21. Jonville, M. C.; Kodja, H.; Strasberg, D.; Pichette, A.; Ollivier, E.; Frederich, M.; Angenot, L.; Legault, J., Antiplasmodial, anti-inflammatory and cytotoxic activities of various plant extracts from the Mascarene Archipelago. J Ethnopharmacol 2011, 136 (3), 525-31.

22. Recio, M. C.; Giner, R. M.; Mánez, S.; Rios, J. L.; Marston, A.; Hostettmann, K., Screening of tropical medicinal plants for antiinflammatory activity. Phytotherapy Research 1995, 9 (8), 571-574.

23. Ali, N. A. A.; Wurster, M.; Denkert, A.; Arnold, N.; Fadail, I.; Al-Didamony, G.; Lindequist, U.; Wessjohann, L.; Setzer, W. N., Chemical Composition, Antimicrobial, Antioxidant and Cytotoxic Activity of Essential Oils of Plectranthus cylindraceus and Meriandra benghalensis from Yemen. Natural Product Communications 2012, 7 (8), 1934578X1200700834.

24. Luqmani, Y. A., Mechanisms of drug resistance in cancer chemotherapy. Med Princ Pract 2005, 14 Suppl 1, $35-48$.

25. Mossa, J. S.; El-Domiaty, M. M.; Al-Meshal, I. A.; El-Feraly, F. S.; Hufford, C. D.; McPhail, D. R.; McPhail, A. T., A flavone and diterpene from Psiadia arabica. Phytochemistry 1992, 31 (8), 2863-2868.

26. Giacinti, C.; Giordano, A., RB and cell cycle progression. Oncogene 2006, 25 (38), 5220-7.

27. Tadesse, S.; Caldon, E. C.; Tilley, W.; Wang, S., Cyclin-Dependent Kinase 2 Inhibitors in Cancer Therapy: An Update. J Med Chem 2019, 62 (9), 4233-4251.

28. Quereda, V.; Porlan, E.; Cañamero, M.; Dubus, P.; Malumbres, M., An essential role for Ink4 and Cip/Kip cell-cycle inhibitors in preventing replicative stress. Cell Death Differ 2016, 23 (3), 430-441.

29. Zhong, Z.; Chen, X.; Tan, W.; Xu, Z.; Zhou, K.; Wu, T.; Cui, L.; Wang, Y., Germacrone inhibits the proliferation of breast cancer cell lines by inducing cell cycle arrest and promoting apoptosis. European Journal of Pharmacology 2011, 667 (1), 50-55.

30. Park, H. S.; Kim, G. Y.; Nam, T. J.; Deuk Kim, N.; Hyun Choi, Y., Antiproliferative activity of fucoidan was associated with the induction of apoptosis and autophagy in AGS human gastric cancer cells. J Food Sci 2011, 76 (3), T77-83.

31. Yoon, J. H.; Gores, G. J., Death receptor-mediated apoptosis and the liver. J Hepatol 2002, 37 (3), 400-10.

32. Sun, S.-Y.; Hail, N., Jr; Lotan, R., Apoptosis as a Novel Target for Cancer Chemoprevention. JNCI: Journal of the National Cancer Institute 2004, 96 (9), 662-672.

33. Mignotte, B.; Vayssiere, J.-L., Mitochondria and apoptosis. European Journal of Biochemistry 1998, 252 (1), 115.

34. Zorova, L. D.; Popkov, V. A.; Plotnikov, E. Y.; Silachev, D. N.; Pevzner, I. B.; Jankauskas, S. S.; Babenko, V. A.; Zorov, S. D.; Balakireva, A. V.; Juhaszova, M.; Sollott, S. J.; Zorov, D. B., Mitochondrial membrane potential. Anal Biochem 2018, 552, 50-59. 
35. Varga, Z. V.; Ferdinandy, P.; Liaudet, L.; Pacher, P., Drug-induced mitochondrial dysfunction and cardiotoxicity. Am J Physiol Heart Circ Physiol 2015, 309 (9), H1453-67.

36. Rahman, K. M.; Ali, S.; Aboukameel, A.; Sarkar, S. H.; Wang, Z.; Philip, P. A.; Sakr, W. A.; Raz, A., Inactivation of NF-kappaB by 3,3'-diindolylmethane contributes to increased apoptosis induced by chemotherapeutic agent in breast cancer cells. Mol Cancer Ther 2007, 6 (10), 2757-65.

37. Karin, M., Nuclear factor-kappaB in cancer development and progression. Nature 2006, 441 (7092), 431-6.

38. Mosmann, T., Rapid colorimetric assay for cellular growth and survival: application to proliferation and cytotoxicity assays. J Immunol Methods 1983, 65 (1-2), 55-63.

39. Abaza, M. S. I.; Al-Saffar, A.; Al-Sawan, S.; Al-Attiyah, R., $\mathrm{c}-<\mathrm{i}>\mathrm{myc}</ \mathrm{i}>$ Antisense Oligonucleotides Sensitize Human Colorectal Cancer Cells to Chemotherapeutic Drugs. Tumor Biology 2008, 29 (5), 287-303.

40. Abaza, M. S.; Bahman, A. M.; Al-Attiyah, R. J., Valproic acid, an anti-epileptic drug and a histone deacetylase inhibitor, in combination with proteasome inhibitors exerts antiproliferative, pro-apoptotic and chemosensitizing effects in human colorectal cancer cells: underlying molecular mechanisms. Int J Mol Med 2014, 34 (2), 513-32. 